\title{
UK Business Perceptions of Sustainability: A Psychological Examination of Theory and Practice
}

\author{
Philip Talbot ${ }^{1} \&$ Michael Brown ${ }^{2}$ \\ ${ }^{1}$ Department of Accounting and Finance Birmingham City University, Business School, City North Campus, \\ Perry Barr, Birmingham B42 2SU, England, UK \\ ${ }^{2}$ Department of Business and Marketing, Birmingham City University, Business School, City North Campus, \\ Perry Barr, Birmingham B42 2SU, England, UK
}

\author{
Received: September 16, 2013 Accepted: October 23, 2013 Available online: November 18, 2013 \\ doi:10.11114/ijsss.v2i1.284 \\ URL: http://dx.doi.org/10.11114/ijsss.v2i1.284
}

\begin{abstract}
The increasing levels of sustainability rhetoric emanating from the UK government and business organisations appear to indicate that the sustainability paradigm has been embraced by UK Business. The degree of this acceptance is examined through the analysis of the annual Britain's Most Admired Companies (BMAC) survey conducted by the British Chartered Management Institute (CMI) between the periods 1994-2011 involving on average two hundred and thirty eight companies per survey. The analysis demonstrates that on every occasion the corporate social and environmental category has ranked last amongst corporate managements' perceptions. These perceptions are evaluated through applying the lens of psychological sustainability and through the education and knowledge of corporate management where traditional financial and management paradigms still dominate. An exception to this status quo is the Co-Op Bank which has dominant sustainability credentials but which has been consistently ranked lower in the overall survey.
\end{abstract}

Keywords: BMAC Survey, community and environmental responsibility, sustainability, management perceptions and psychology

JEL codes: M10, M14.

The journey metaphor translates sustainability (and sustainable development) into a never ending process.

(Milne, Kearins and Walton: 2006)

\section{Introduction}

\subsection{Sustainability Overview}

It is now generally accepted that the sustainability paradigm in one guise or another is an important aspect of UK modern business. This is publically disclosed and reported thereby allegedly ensuring the accountability, green and ethical credentials of each company to its stakeholder audience. Lord Taylor of Holbeach the Environment Minister has stated that, "British firms are world leaders in understanding that improving the sustainability and resilience of their whole business is not only good for the environment but good for the bottom line too. This new guidance is another step towards our aim of corporate sustainability reporting becoming normal business practice by making it as simple as possible for companies to show their environmental impact" (Defra, 2012).This paper attempts to evaluate the commitment and the importance accorded to sustainability issues by contemporary UK companies by analysing data created out of the annual BMAC survey conducted between the period 1994-2011. At the same time this approach will endeavour to contextualise management attitudes through a psychological behavioural and knowledge attitude to explain why sustainability consistently is accorded to rank least amongst a company's concerns. It will be argued that this can be attributed psychologically to human (management and reporting) behaviour within their social environment by applying the psychological arguments advanced by Faber, Peters, Maruster, Van Haren and Jorn, (2010).

\section{UK Government Frameworks}

\subsection{The Official UK Sustainability Agenda}

The well-known and generally accepted international starting point for defining sustainability remains the influential 1987 report 'Our Common Future published by the World Commission on Environment and 
Development' (Brundtland Report) which stated that, "Humanity has the ability to make development sustainable - to ensure that it meets the needs of the present without compromising the ability of future generations to meet their own need" (Gray and Bebbington, 2001:295). However, this definition is open to criticism and is also short on detail which has been accused of being a "slick cliché due to overuse, misuse and abuse by policy makers and politicians" (Cooper, 1995). Nonetheless, the wider acceptance of this doctrine led to CSR (corporate social reporting) being reluctantly acknowledged as victorious since "CSR has won the battle of ideas albeit that it was a pity" (Crook, 2005). An influential example of the success of the green agenda was the publication of the UK Stern Review (2007) conducted by Sir Nicholas Stern, Head of the UK Government Economic Service and adviser to the Government on the economics of climate change and development who concluded that, "while the economic costs of greenhouse gas emissions to environmentally sustainable levels would be high, the costs of (not) dealing with the significant negative effects ... would be many times higher." (Hopwood, Unnerman and Fries, 2010:5). The adoption of the green/sustainability agenda though is a wider global movement and increasingly governments have been fostering CSR, amongst which the UK remains a leading proponent with its own CSR minister alongside the European Union White Papers on policy and the recent European Alliance for CSR (Visser, Matten, Pohl and Tolhurst, 2010: x).

The UK government's position is detailed in its strategic framework One Future-Different Paths (2005) which is a development of its earlier 1999 strategy. The 1999 strategy set out clearly that sustainable development means a better quality of life for everyone, now and for generations to come aping the Brundtland definition. The four aims developed for the 1999 strategy were:

- Social progress which recognises the needs of everyone;

- Effective protection of the environment;

- Prudent use of natural resources; and

- Maintenance of high and stable levels of economic growth and employment.

(Defra, 2005:6)

The UK government added that for a policy to be sustainable it must respect all principles (Defra, 2005:8) and as with the Brundtland approach it proclaims broad principles with inadequate supporting details. This commitment has developed incrementally and the current UK coalition government has produced "Enabling the Transition to a Green Economy: Government and business working together" (HM Government, 2012). This demonstrates a major commitment towards creating a "green economy" which, will be achieved "through working together through concerted action across Government, but also through Government working together with businesses and with civil society" (HM Government 2012:3) outlined in Table 1.

Table 1. UK Government Transition to a Green Economy (2012)

\begin{tabular}{l} 
Government Intentions \\
\hline Develop a green policy framework which: \\
Is effective, clear, stable and as streamlined and minimally \\
burdensome as possible;
\end{tabular}

Encourages investment;

Protects existing investments, where possible, through use of 'grandfathering' (protecting pre-existing rights).

Promote the UK as a global leader in green exports and encourage green inward investment

Provide accessible advice and support to enable businesses to increase their resource efficiency, resource security and resilience to climate change

Ensure that Government 'green' policies take

into account the competitiveness of UK-based companies, including Energy Intensive Industries and develop measures to support businesses most hit by transitional costs

\section{Business Hoped for Responses}

Work with Government to:

explore voluntary approaches to greening products and services;

Identify areas of green policy and regulation which can be streamlined whilst remaining effective;

Invest in greener products, services and production processes.

Help Government publicise the skills and expertise of UK-based business.

Become increasingly resource efficient and build risks of energy/resource security and climate change into future business planning.

Continue to explore production processes and business models which reduce use of resources and carbon emissions 
Ensure the skills system responds to the demand for skills created by shift to green economy.

Support the development of greener products, services, and technologies, though continued support for R\&D and innovation.

Encourage investment in infrastructure and ensure that infrastructure supports the green economy, including through the Green Investment Bank

Enable UK-based businesses to compete in green, low carbon supply chains where the UK has expertise

Procure products that meet cost-effective sustainability standards.

Help businesses understand the value of and their impact on the natural environment.
Help articulate skills demand through involvement in LEPs, and Sector Skills Councils Design, develop and promote greener products and services, including enabling technologies.

Invest in infrastructure that will support the green economy.

Work together, where possible, to help build UK-based supply chains.

Adopt sustainability standards for their procurement

Consider the value of the natural environment to their business.

(HM Government 2012:11)

Therefore, both the UK government's championing of the sustainability agenda backed by the mainstream UK industry and its related organisations such as the Confederation of British Industry (CBI) would imply the success of this green agenda which could be expected to be reflected in the BMAC surveys. This plausibility appeared accurate when a former and recent Director General of the CBI stated that, "Responsible businesses are at the heart of society. Companies that understand their links with the communities they operate in, and their impact on the environment, are most likely to prosper in the long-term. At the same time, interest from stakeholders in firms' environmental performance is at an all-time high. The Accounts Modernisation Directive means that whether you are a plc or a large private company, you will need to report to investors on how environmental issues will affect your profitability. And growing environmental awareness means more firms than ever are coming under scrutiny from community groups and NGOs" Sir Digby Jones, Director General CBI, (Defra, 2006:3).

However, this strong industry support has more recently been critical of government policies, with the current CBI director, John Cridland stating, "The so called "choice" between going green or going for growth is a false one. We are increasingly hearing politicians are either for one or the other, when in reality, with the right policies in place, green business will be a major pillar of our future growth" (CBI, 2012). Nonetheless, the overall political and business environment would appear to favour strong support for this green agenda amongst UK companies and the CBI as representative of business has produced their own policies outlined in Table 2 of recommendation in response to the government's proposals.

Table 2. CBI

\section{Recommendations for Government}

Maintain the UK's ambition

Ensure that the ambition of the 4th Carbon Budget is maintained, if underpinned by a smart UK policy framework which follows the recommendations of this report, and matched with consistent messaging from all parts of government

Play a strong role in Europe and internationally

$\mathrm{Be}$ at the forefront of shaping the future of the EU Emissions Trading Scheme and global climate negotiations
Reflect the value of all sectors in the economy

Develop a long-term strategy for energy-intensive industries, including the further rollout of realistic sector specific decarbonisation roadmaps, which will enable them to fulfil their role in the low-carbon transition

Build upon the UK's strengths

Play a more proactive role in aligning policy and investment with existing UK strengths, and promoting these abroad 
Establish clear and stable market frameworks

Ensure that market signals - particularly within the reformed electricity market - have stability and longevity, with any adjustments made in a pre-defined way.

\section{Stimulate new consumer markets}

Work collaboratively with business to ensure the right mix of incentives and regulation, together with clear and consistent information, is in place to drive demand in emerging markets such as the Green Deal

Cut 'green tape'

Reduce complexity in the existing low-carbon policy landscape, including immediate action on the Carbon Reduction Commitment, and take a more strategic approach when developing future policies
Capture greater value from green investments

Identify opportunities to develop domestic capabilities through targeted interventions and longer-term technology road-mapping

Facilitate the flow of finance

Give the Green Investment Bank the power to raise funds from the capital markets as soon as is fiscally possible, while ensuring that priority projects are also eligible for direct government intervention in the short-term

Develop our 'intellectual infrastructure'

Continue to support the UK's strong innovation ecosystem, and address strategic skills shortages

\section{Britain's Most Admired Companies}

\subsection{The Annual BMAC Survey}

The success of this agenda will now be tested through the BMAC survey. Since 1990, the BMAC survey has polled senior executives in companies with the highest market capitalisation on the London Stock Exchange. This process has provided data over a 19-year period producing approximately 3 million observations. The BMAC surveys provide continuity of data since $35 \%$ of the companies that have taken part were in both the first and the latest survey. The data therefore provides insights as to the importance of sustainability and its ranking within the corporate agenda and its relationship with other corporate factors. The data is published in the latter part of each year in the UK Chartered Institute of Management's (CIM) journal "Management Today". The survey has been conducted for over two decades in conjunction with Professor Michael Carter now professor of corporate reputation and strategy at Birmingham City Business School. The survey focuses on the UK's largest companies in twenty-five separate business sectors consisting of up to ten companies per sector. Senior executives of each participating company are invited to provide their perceptions for other companies within the sector within they operate (i.e. banking, building materials and merchants, chemicals, construction-heavy, construction-home, engineering-aero and defence, engineering and machinery, food producers and processors, health and household, leisure and hotels, life assurance and insurance, media, oil, gas and extractive, paper and packaging, property, restaurants and breweries, retailers-food and personal, retailers-general /home, retailers-specialist, software and computer services, speciality and other finance, support services, telecommunications and transport) across each of nine characteristics that determine a company's overall score. These characteristics comprise; the quality of management (QM); financial soundness (FS); the quality of products (QP); the ability to attract retain and develop top talent (AADRT); value as a long term investment (VLTI); the capacity to innovate (CI); the quality of marketing (QMar); community and environmental responsibility (C\&ER) now regarded as sustainability; and the use of corporate assets (UCA). A company's characteristics are scored on a Likert scale of $0-10,(0=$ poor, $5=$ average and $10=$ excellent $)$. Bipolar scales in the form of opposite adjectives, poor to excellent, capture the respondents' attitudes towards each company within the sector, for each of the aforementioned characteristics. This permits average individual company total scores out of 90 to be calculated for of all the entities involved and these are then ranked within each business sector and in an overall league table.

\section{Management Psychology}

\subsection{Psychology: Management Behaviour and Knowledge: The Dominance of Economics}

Since these corporate evaluations for the survey are founded on executive perceptions psychology as the scientific study of the human mind and its functions and how it affects human behaviour is considered to be an appropriate discipline to evaluate the BMAC participants' awareness. In addition this approach would respond to 
the call by psychologists for an interdisciplinary approach towards sustainability (Pelletier, Lavergne and Sharp, 2008 and Faber et al 2010:8). They have argued that economics (and by implication accounting and finance) in the sustainability agenda has remained the dominant discipline to attract official attention because, “...their statements of the costs and benefits of proposed policies in monetary terms use the same metric as government budgets" (McKenzie-Mohr and Oskamp, 1995:6). Arguably the same financial imperatives may be attributed to business and its concerns with its financial metrics and financial statements. This is perceived as according mainly a technical and normative focus (Jorna 2006, Meppem and Gill 1998) and attention to corporate sustainability has tended to focus on how change can be achieved at organisational level (Tang, Robinson and Harvey 2011:1372). Ultimately sustainability's success it is stated will be influenced by a collective human behaviour which will in turn influence the behaviour of companies and their managements. Thus far sustainability has been largely a top-down driven approach imposed by international governmental bodies, national governments and trade associations which are enforced through processes of political bargaining and enforced by legislation and rules of conduct (Jorna: 2006), e.g. the UN's Global Reporting Initiative, the UK Stern Review (2006), the UK government's "Enabling the Transition to a Green Economy: Government and business working together" (2012).

\subsection{Psychology and Sustainability; Artificial Constructions}

Faber et al (2006) in their work adopted the notion of human behaviour and sustainability issues being conceptualised within a concept of an artificial system that draws upon the earlier works of (Simon 1969 and Von Bertalanffy 1951). In essence an artificial system is any one system devised, constructed and operated by humans (Tiettenberg, 2000) in this case it is taken to mean the company and corporate management. These companies then exploit the resources of the earth but these resources themselves remain as an artificial system because although they comprise a natural resource they are used for a purpose which is human oriented to ultimately generate profit. Employing this definition of artificial systems and how they are deployed will be constrained by human choices and actions that will be founded on the (sustainability) knowledge and education of the humans' involved (corporate management) who are operating within and controlling this artificial system.

Consequently corporate management education, knowledge, its behaviour and attitudes will influence the behaviour of the system (company) which it operates that in this instance would be the dynamic equilibrium between the artificial system and its natural environment which becomes the company's sustainability policy (Tiettenberg, 2000). The survival of these sustainability systems will be reliant on the dynamics of the human (corporate management) interaction with the system which can change over time and subsequently affect human (management) behaviour. In addition sustainability becomes a relative rather than an absolute goal since sustainability is not a definite state which can be realised so it relies on a continuing process of improvement based on evolving knowledge systems and the interaction of corporate activity with the environment. This in turn rests upon the development of human (management) knowledge and corporate behavioural changes of the management class which controls the artificial system and by adopting new targets for attaining new equilibriums between these artificial systems, the corporate behaviour and its interactions with the environment. This presents a fundamental problem because it is in the nature of human corporate activity to exploit, destroy, repair and construct materials and artefacts through knowledge and social structures that permit this to occur but which may be used to understand and reposition. This understanding for the storage, creation and application of knowledge as a theory of knowledge management thus becomes essential (Jorna 2006, McElroy 2009).

\subsection{Knowledge Management and Education}

Faber et al (2006) identify two key concepts within knowledge management formation and sustainability. Firstly there is a concept of knowledge content in this instance sustainability which focuses on what knowledge is and in what domain it is placed within a corporate hierarchy of objectives. Thus, knowledge of sustainability is recognising the factors that create the problems which are identified as causing sustainability issues. Then following this stage it requires constructing organisational solutions and behaviours to redress these problems. This will demand that that managers need to change corporate behaviour based on decision-making derived from increased knowledge and learning about sustainability. The second concept refers to those processes which govern the generation of (sustainability) knowledge and how it is applied which, requires learning new methods both as individuals (managers) and at group levels (companies). Since sustainability is a relatively new business discipline that is an evolving and mutating process which will require all players to adapt to new sustainability issues, i.e. the artificial systems (companies) behaviour becomes updated and modified. The crux to this successfully occurring is that the individuals (managers) and company respond accordingly via the organisations knowledge cycle, Table 3 to maintain the artificial systems interaction with the environment. 
Table 3. The Organisational Knowledge Cycle

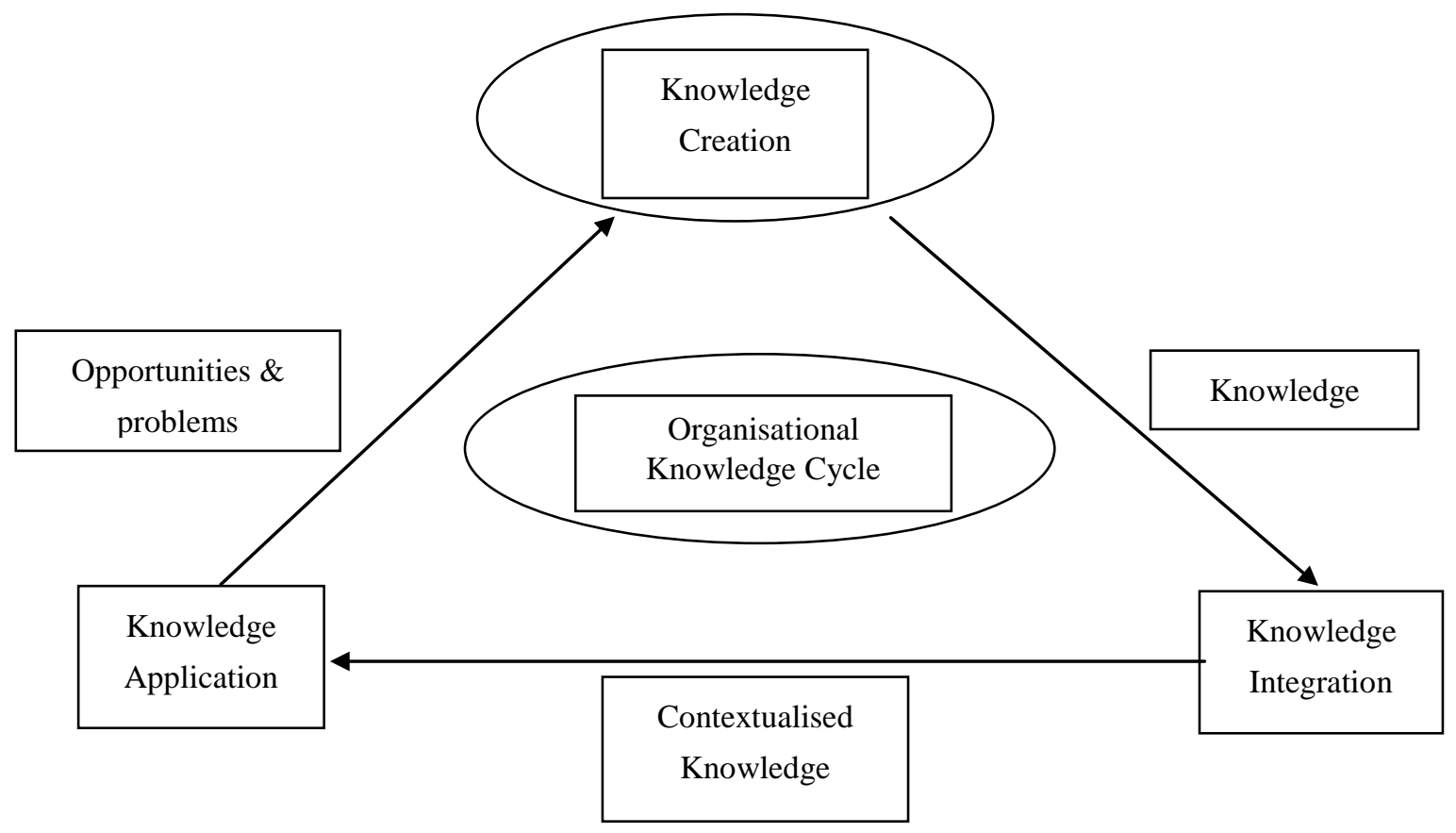

(Faber et al 2010:6)

It is intended to examine the extent to which this new knowledge of sustainability has been embraced by UK companies through the data of the BMAC survey 1994-2011 rather than relying on the sustainability rhetoric of government and organisational bodies.

\section{Evaluating Perceptions and Trends of Sustainability}

\subsection{BMAC Ratings 1994-2011}

Presented graphically below in Table 4 are the average BMAC results for each individual year and in Table 5 the average scores for the period to illustrate the trends in the individual categories of measurement reflecting management's overall psychological perceptions of importance.

Table 4. BMAC Most Admired Companies (1994-2011); \% Scores by Category

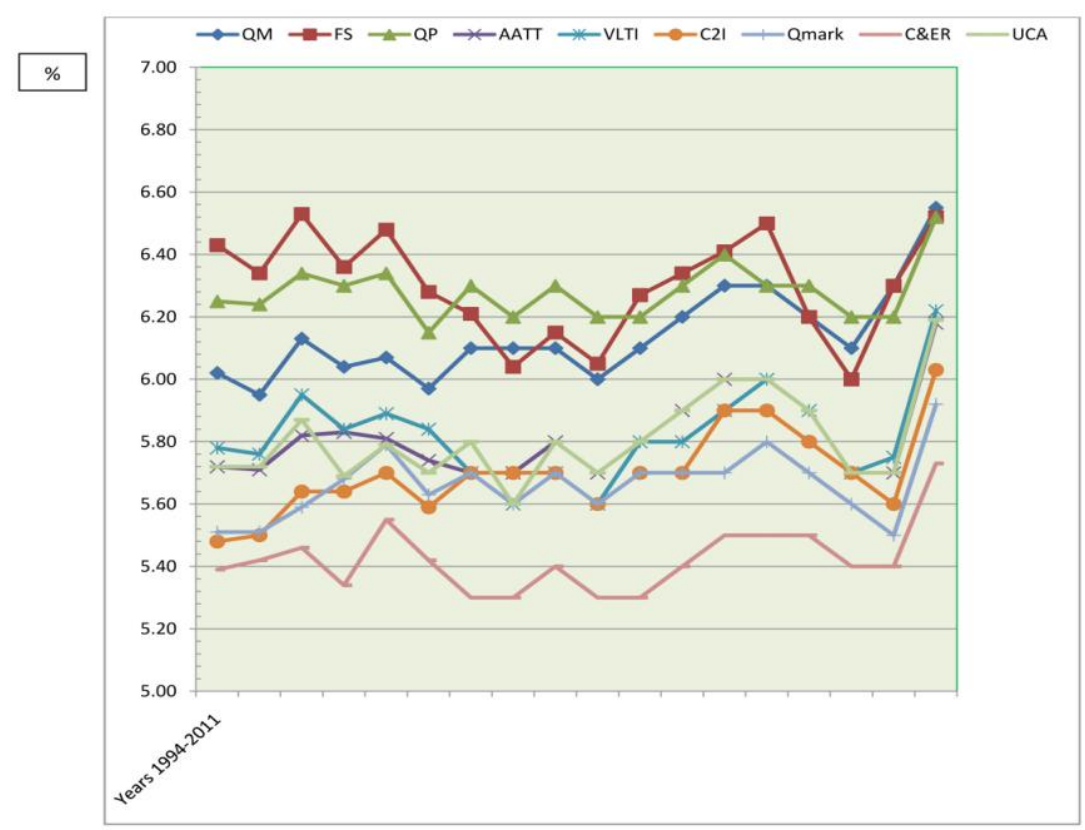


Legend

\begin{tabular}{|c|c|c|c|c|c|c|c|c|c|}
\hline AATT $=$ & $\begin{array}{l}\text { Attract, } \\
\text { retain, } \\
\text { develop }\end{array}$ & $\mathrm{C} 2 \mathrm{I}=$ & $\begin{array}{l}\text { Capacity to } \\
\text { innovate }\end{array}$ & $\mathrm{C} \& \mathrm{ER}=$ & $\begin{array}{l}\text { Community, } \\
\text { environmental } \\
\text { responsibility }\end{array}$ & $\mathrm{FS}=$ & $\begin{array}{l}\text { Financial } \\
\text { soundness }\end{array}$ & $\mathrm{QP}=$ & $\begin{array}{l}\text { Quality of } \\
\text { goods and } \\
\text { services }\end{array}$ \\
\hline $\mathrm{QM}=$ & $\begin{array}{l}\text { Quality } \\
\text { of } \\
\text { management }\end{array}$ & QMark= & $\begin{array}{l}\text { Quality of } \\
\text { marketing }\end{array}$ & $\mathrm{UCA}=$ & $\begin{array}{l}\text { Use } \\
\text { of corporate } \\
\text { assets }\end{array}$ & VLTI= & $\begin{array}{l}\text { Value as a } \\
\text { long term } \\
\text { asset }\end{array}$ & & \\
\hline
\end{tabular}

Table 5. BMAC Overall Average \% Scores by Category (1994-2010)

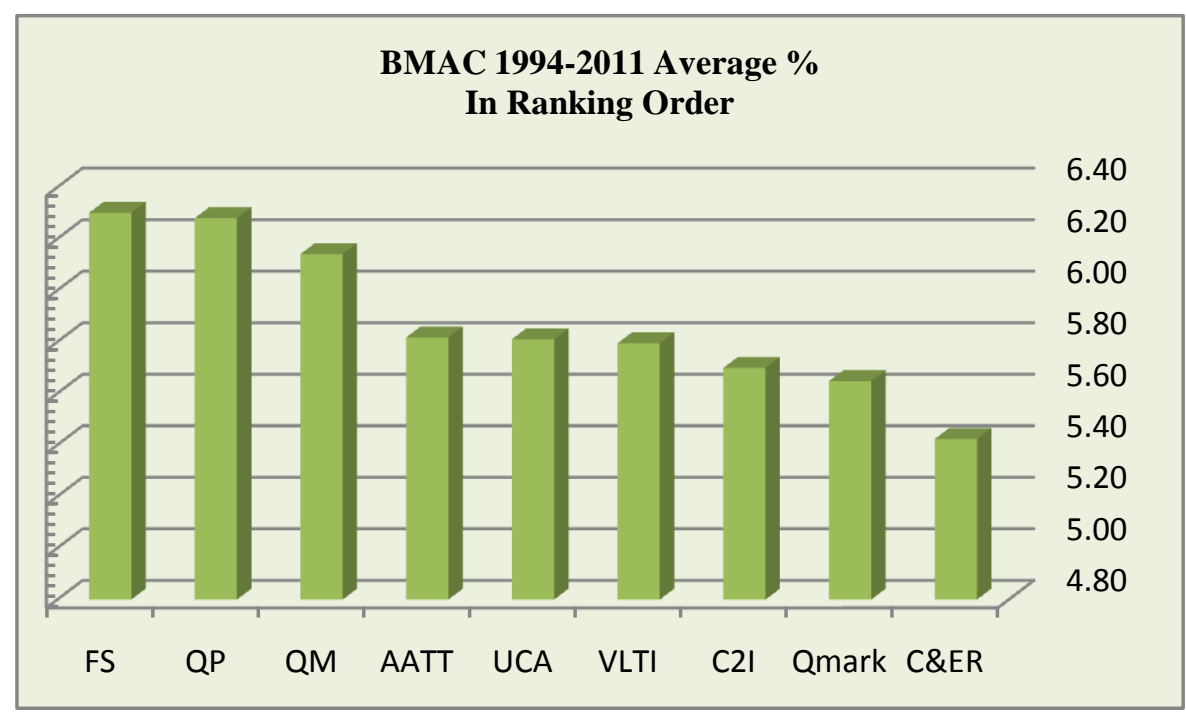

It is readily apparent that throughout the period 1994 to 2011 the C\&ER category has consistently ranked last amongst all the categories indicating that it is perceived by most companies and their management as being the least important which may reflect a lack of fully understanding the sustainability agenda.

\subsection{A Corporate Exception}

However, as always there is an exception to the rule and the general picture of sustainability issues ranking last amongst the corporate psychological awareness is to be consistently found in the performance of the mutual Co-Operative Bank over the period 2007-2011 (albeit it chose not to participate in the survey in 2008 and did not participate prior to 2007). The overall 2011 top ten company positions are provided in Table 6.

Table 6. BMAC Leading 10 Companies; C\&ER 2011

\begin{tabular}{|c|c|c|c|c|}
\hline & C\&ER Score & $\begin{array}{c}\text { Overall } \\
\text { Score }\end{array}$ & $\begin{array}{l}\text { C\&ER \% of } \\
\text { Total Score }\end{array}$ & $\begin{array}{l}\text { Overall } \\
\text { Position }\end{array}$ \\
\hline 1 Diageo & 8.08 & 72.35 & $11.17 \%$ & 2 \\
\hline 2 British Land Company & 7.94 & 59.4 & $13.37 \%$ & 79 \\
\hline 3 Marks \& Spencer & 7.83 & 64.9 & $12.06 \%$ & 33 \\
\hline 4 Land Securities & 7.8 & 65.8 & $11.85 \%$ & 26 \\
\hline 5 Co-operative Group & 7.7 & 53.1 & $14.50 \%$ & 157 \\
\hline 6 Coca-Cola Enterprises & 7.67 & 65.8 & $11.66 \%$ & 26 \\
\hline 7 Croda International & 7.58 & 64.5 & $11.75 \%$ & 37 \\
\hline 8 Unilever & 7.57 & 69.9 & $10.83 \%$ & 8 \\
\hline 9 Sainsbury $(\mathrm{J})$ & 7.55 & 60.8 & $12.42 \%$ & 66 \\
\hline 10 BASF (UK) & 7.50 & 67.8 & $11.06 \%$ & 12 \\
\hline Average & 7.72 & 64.43 & $12.07 \%$ & 44.60 \\
\hline 17 Co-Operative Bank & 7.1 & 52 & $13.65 \%$ & 173 \\
\hline
\end{tabular}

In the overall top leading companies a top ten C\&ER score is only reflected by two companies, i.e. Diageo and Unilever given in Table 7 below. 
Table 7. BMAC Leading 10 Companies 2011

\begin{tabular}{lcccc}
\hline & $\begin{array}{c}\text { Overall } \\
\text { Score }\end{array}$ & C\&ER & C\&ER & $\begin{array}{c}\text { C\&ER } \\
\text { Position }\end{array}$ \\
\hline 1 Berkely Group & 72.95 & 6.8 & $9.32 \%$ & 28 \\
2 Diageo & 72.35 & 8.1 & $11.17 \%$ & 2 \\
3 Rotork & 71.6 & 6.8 & $9.50 \%$ & 26 \\
4 Aggreko & 71.2 & 5.1 & $7.16 \%$ & 121 \\
5 Derwent London & 70.9 & 6.7 & $9.45 \%$ & 30 \\
6 Paddy Power & 70.29 & 5.3 & $7.54 \%$ & 151 \\
7 Royal Dutch Shell & 70.24 & 6.7 & $9.54 \%$ & 32 \\
8 Unilever & 69.29 & 7.6 & $9.83 \%$ & 8 \\
9 Rolls Royce & 68.35 & 6.6 & $9.24 \%$ & 33 \\
10 Shaftesbury & 68.2 & 6.3 & $9.34 \%$ & 63 \\
Average & 70.54 & 6.6 & $13.65 \%$ & 49.4 \\
173 Co-Operative Bank & 52 & 7.1 & 17 \\
\hline
\end{tabular}

The psychological consciousness of Diageo's and Unilever's green credentials are reflected in their stated public policies and extensive reporting disclosures on their websites and for context these are briefly reviewed below. Diageo claims that, "it believes that our success as a company is measured by more than just financial targets. The positive contribution we can make to lives, communities and the environment through good business is important to our long-term success" and produces a comprehensive annual stand alone sustainability and responsibility report which it has done so since 2003. The report forms part of their overall corporate disclosures and employs the Global Reporting Guidelines (GRI) as a framework with limited independent attestation provided by the international accountancy firm KPMG.

Unilever, (the overall BMAC winner in 2010) was amongst the other top ten entries in the C\&ER category. In 2010 it adopted a new green strategy and launched its "Sustainable Living Plan" which is similar to Marks \& Spencer's Plan A and the Co-Op Group's "Join the Revolution" strategy launched in 2011, it will be noted that the Co-Op Group ranked fifth in the C\&ER table. This is supported by extensive information and videos on its corporate website Nonetheless; in general the analysis indicates that C\&ER /sustainability have not been accorded a high priority amongst the majority of leading companies because it perennially retains its ninth rank overall classification.

Contrastingly the Co-Operative Bank's performance ranking and C\&ER score over the period is presented in Table 8 achieving a consistent score of seven plus but having risen in 2011 by 0.37 points or $5 \%$ demonstrating a consistent high level of psychological awareness of the sustainability schema.

Table 8. Co-Op Bank C\&ER Positions 2007-2011

\begin{tabular}{cccccccccc}
\hline 2011 & $\begin{array}{c}\text { C\&ER } \\
\text { Rank }\end{array}$ & 2010 & $\begin{array}{c}\text { C\&ER } \\
\text { Rank }\end{array}$ & 2009 & $\begin{array}{c}\text { C\&ER } \\
\text { Rank }\end{array}$ & 2008 & $\begin{array}{c}\text { C\&ER } \\
\text { Rank }\end{array}$ & 2007 & $\begin{array}{c}\text { C\&ER } \\
\text { Rank }\end{array}$ \\
\hline 7.1 & 17 & 7.75 & 1 & 7.38 & 4 & N/A & N/A & 7.4 & 4 \\
\hline
\end{tabular}

The Co-op Bank's individual category scores for 2011 shown in Table 9 were as follows showing C\&ER is strikingly different as it ranks first amongst categories in contrast to the overall averages and has done so in all of its participation in the annual surveys.

Table 9. Co-Op Bank 2011 Performance and Position

\begin{tabular}{lccccccccc}
\hline & FS & QP & QM & AATT & VLTI & UCA & C21 & Qmark & C\&ER \\
\hline Score & 5.6 & 6.0 & 5.9 & 4.7 & 5.3 & 5.8 & 6.1 & 5.6 & 7.1 \\
Position & 188 & 176 & 180 & 218 & 196 & 162 & 115 & 152 & 17 \\
Ranking & $6=$ & 3 & 4 & 9 & 8 & 5 & 2 & $6=$ & 1 \\
All companies average ranking & $2=$ & $2=$ & 1 & 6 & 4 & 5 & 7 & 8 & 9 \\
\hline
\end{tabular}

The Co-Op Bank with its focus on responsible finance has been recognised by being named recognised as the most sustainable bank in Europe (this occurred in 2010 and 2011, and also in 2012, Financial Times Award, and has annually achieved this UK status since 2007). The bank claims a long-standing ethical approach to finance dating from 1992 and reviewed this policy in 2009 that is unique in UK retail banking. This includes the provision that responsible finance is crucial to sustainable development which extends to include a portfolio of targeted sectors that promote sustainable development including renewable energy, energy efficiency, charity and social enterprise sectors. The bank's ethical policy is mandated by its customers who restrict the provision of financial services to certain activities and sectors. This extends to cover all non-personal assets and liabilities held on the bank's balance sheet, e.g. retail and syndicated loans, corporate leasing, retail deposits and savings, 
and treasury dealings, and the investment of all retained balances. In 2011 the ethical policy was extended to include investments underpinning insurance home insurance and motor insurance policies.

The graph in Table 10 clearly exemplifies that the Co-Op Bank's superior C\&ER performance against the average in respect of all other categories where it is mostly below the average. The dominance of the C\&ER substantiates the organisation's long-standing adoption and capacity to embrace sustainability as its leading dynamic.

\subsection{Co-Operative Bank Reputation Damaged}

Since the analysis given above was constructed the Co-Operative bank has experienced severe and continuing financial difficulties during 2012 and 2013. The bank has faced a shortfall in its balance sheet of $£ 1.5$ billion arising from a series of bad loans, an expensive and unsuccessful acquisition of a building society, and costly write downs from a failed IT system and witnessed its debts being downgraded to junk status alongside a reported loss $£ 673.7$ million in 2013. This has led to changes of senior management and mutualisation being forfeited to become a listed company on the London Stock Exchange. The ensuing criticisms of the management by the business media have extended to the avowed sustainability policies of the bank by alleging that too much focus has been accorded to this area at the expense of more traditional management disciplines.

Table 10. The CO-OP Bank Category Performance and Others Overall Performance 2011

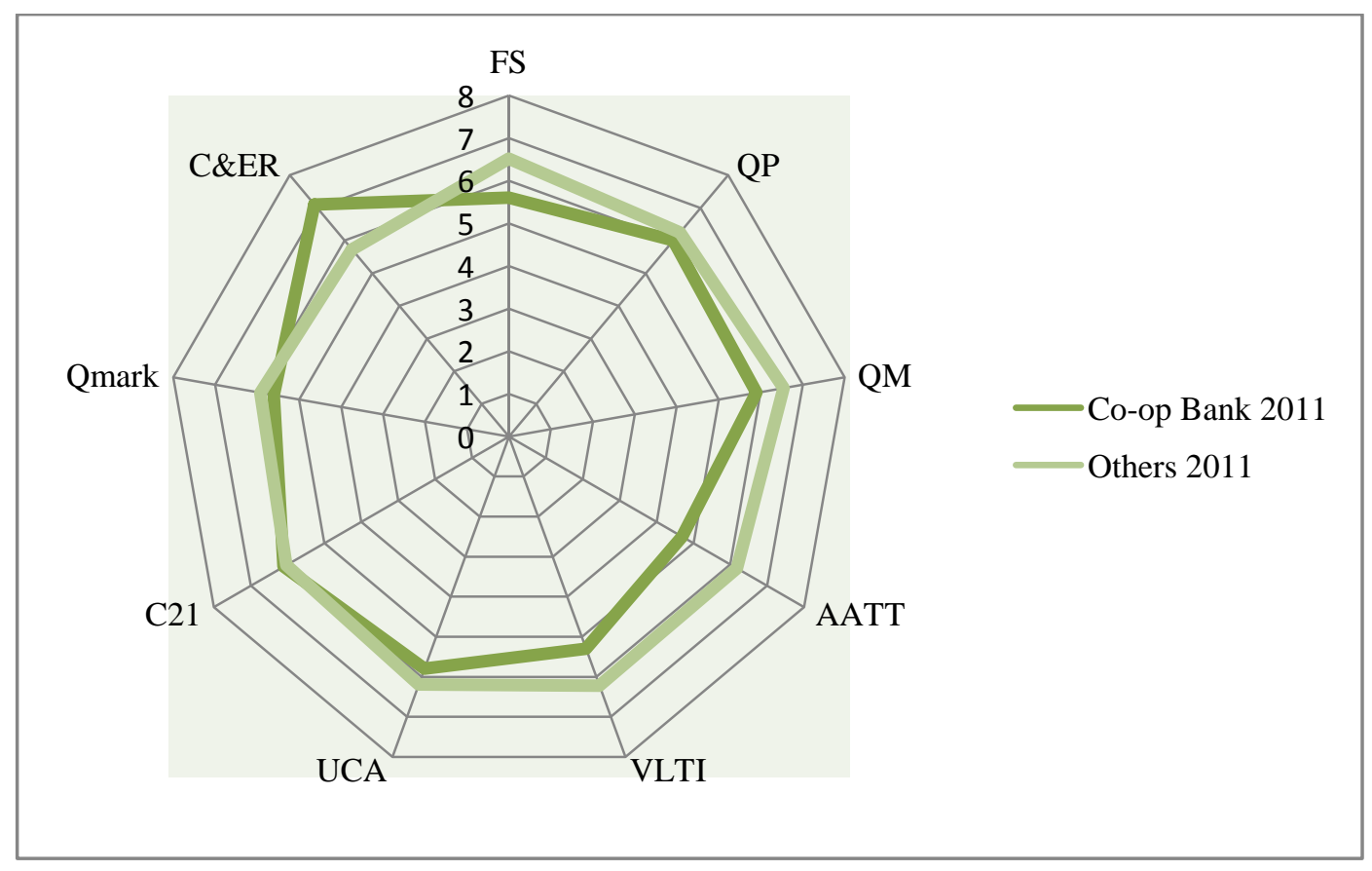

\section{Conclusion}

\subsection{Corporate Sustainability Trends}

The trend in C\&ER scores is detailed in Table 11.In 2011 the average C\&ER score noticeably increased to attain its highest ever average of 5.73 but this category displays uneven trends of rising and falling over the period especially during downturns in the economic cycle experienced between 2008 and 2009. The rise may reflect a slowly changing response of companies as artificial systems and the behaviour of its management as it psychologically responds to the wider availability of sustainability knowledge, education and behaviour as identified by Faber et al thus increasingly influencing corporate perceptions which can only be evidenced from future results. Even so the 2011 increase in C\&ER scores was not unique as all other sectoral scores also increased. The C\&ER scores in turn may have been driven by top-down initiatives by the UK government and CBI influencing the behaviour of corporate management. 
Table 11. BMAC C\&ER Trends (1994-2011)

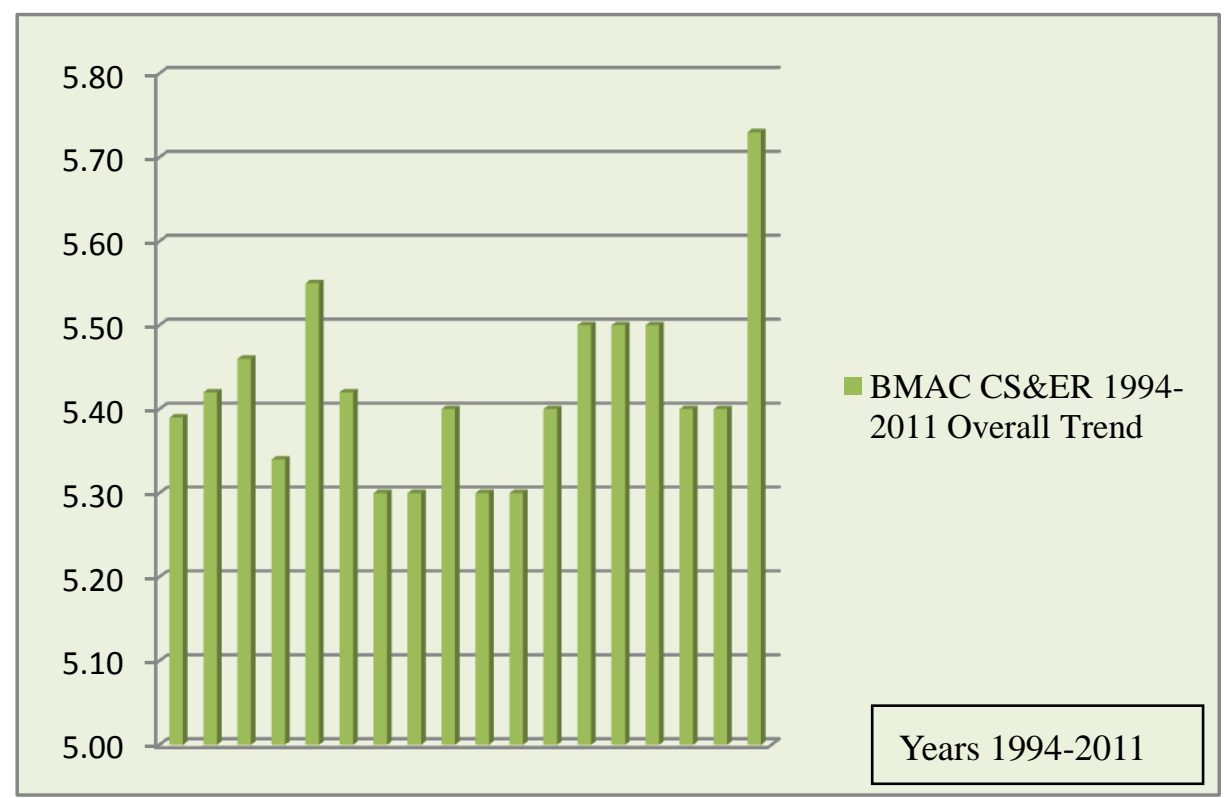

Nevertheless, it is evident that that the leading modes of corporate knowledge have maintained their dominance over the period, i.e. financial soundness, the quality of management and the quality of goods and services. This is unsurprising given that within a capitalist system the dominant social paradigm favours the values of economic wealth, power and control over the environment and willingly risk eco-systems, and the degradation and disruption of global biogeo-chemical systems to maximize those values. This type of belief system has become embedded in the capitalist culture and supporting business education systems which are largely unquestioningly accepted and assumed rather articulated in discourse (Milbraith, 1995:106-107). This is inevitably in conflict with the sustainability paradigm although these issues have become more widely known since 1995 when Milbraith enunciated his criticisms.

A follow up survey conducted arising from the BMAC 2011 results asked the companies to explain what they identified as constituting C\&ER. The feedback was disappointing registering just under a $25 \%$ response rate. Most comments were bland which could be mainly categorised as fitting into the "good corporate citizen" context accompanied by limited explanation. However, one respondent labelled C\&ER succinctly and dismissively as a "buzz word" indicating that at least some psychological resistance to the sustainability paradigm remains firmly entrenched. This reflects Gifford's (2008: 274) view which argues that "individuals are truly the ultimate key to climate amelioration: policies, programmes and regulations themselves do not change anything... policies must be "bought into" by individuals. In short, policy beckons or even commands but persons accept or refuse its demands. Behavioural change does not occur until this happens".

Even so the evidence indicates that C\&ER psychological awareness is currently increasing to higher levels than hitherto (albeit previous higher levels have not always been maintained) but generally continues to be ranked last amongst business priorities. Where C\&ER features prominently in an individual company profile such as the Co-Op Bank then this remains exceptional as this characteristic is distinguishable in only two of the top ten ranking companies, i.e. Diageo and Unilever. The remaining top ten companies in the survey average a C\&ER score of $8.97 \%$ where the top ten C\&ER tipping point for entry is $12.07 \%$ showing a considerable gap for improvement. Nonetheless, it is notable that some of these ranking top companies are perceived as being very poor in C\&ER terms, i.e. Aggreko - generators and refrigeration $\left(121^{\text {st }}\right)$, and Paddy Power - gambling $\left(151^{\text {st }}\right)$. If the top ten companies have attained such poor C\&ER scores and rankings it reflects that sustainability issues in some companies remain as an add on to modern business practice and that the psychology of management and corporate behaviour has yet to fully embrace the sustainability agenda while the older paradigms remain dominant.

\section{References}

Brundtland. (1987). Report of the World Commission on Environment and Development: Our Common Future, UN Documents, www.un-documents.net/wced-ocf.htm

CBI. (2012). The colour of growth: Maximising the potential of green business. www.cbi.org.uk/campaigns/maximising-the-potential-of-green-business/ 
Co-Operative Group, www.co-operative.coop/corporate/sustainability/social-responsib...

Co-Operative Group, “Join the Revolution, Ethical Plan”, www.co-operative.coop/join-the-revolution/

Cooper. C. L. (1995). "Sustainable Development - A Slogan or Strategy", COSMOS Journal- A Journal of Emerging Issues, 14.

Crook. C. (1995). The Good Company: A Special Report on Corporate Social Responsibility. The Economist, 374(8410), 3.

Department for Environment, Food and Rural Affairs. (2005). One future - different paths: The UK's shared framework for sustainable development, archive.defra.gov.uk/sustainable/government/publications/uk-str....

Department for Environment, Food and Rural Affairs. (2006). Environmental Key Performance Indicators $\begin{array}{llll}\text { Reporting Guidelines } & \text { for } & \text { Business, }\end{array}$ archive.defra.gov.uk/environment/business/reporting/pdf/envkpi-guidelines.pdf.

Department for Environment, Food and Rural Affairs. (2012). New guidance for businesses to report their sustainability credentials. https://www.gov.uk/government/news/new-guidance-for-businesses-to-report-th...

Diageo, www.diageo.com/en-row/CSR/

Faber, N. R, Peters, K., Maruster, L., Van Haren, \& Jorn, R. (2010). Sense Making of (Social) Sustainability a Behavioural and Knowledge Approach. International Studies of Management and Organisation, 40(3), 8-22. http://dx.doi.org/10.2753/IMO0020-8825400301

Gifford. R. (2008). Psychology's essential role in alleviating the impacts of climate change, Canadian Psychology, 49(4), 273-80. http://dx.doi.org/10.1037/a0013234.

Gray, R., \& Bebbington, J. (2001). Accounting for the Environment, $2^{\text {nd }}$ Ed, London, SAGE Publications.

HM Government. (2012). Enabling the Transition to a Green Economy: Government and business working together. https://www.gov.uk/government/news/encouraging-green-growth-government-and-...

Hopwood, A., Unnerman, J., \& Fries, J. (2010). Accounting for Sustainability Practical Insights, London, Earthscan

Jorna, R. J. (2006). Sustainable Innovation: The Organisational, Human, Knowledge Dimension, Sheffield, Greenleaf.

Milbraith, L. W. (1995). Psychological, Cultural, and Informational Barriers to Sustainability. Journal of Social Issues, 51(4), 101-29.

Milne, M. J., Kearins, K., \& Walton, S. (2006). Creating Adventures in Wonderland: The Journey Metaphor and Environmental Sustainability. Organization, 13(6), 801-839.

Meppem, T., \& Gill, R. (1998). Planning for Sustainability as a Learning Concept. Ecological Economics, 6(2), 121-137.

Pelletier, L. G, Lavergne, K. J., \& Sharp, E. C. (2008). Environmental Psychology and Sustainability: Comments on Topics Important for Our Future. Canadian Psychology, 49(4), 304-8. http://dx.doi.org/10.1037/a0013658.

Simon, H. A. (1969). The Sciences of the Artificial, Cambridge, MIT Press.

Stern, N. (2007). The Economics of Climate Change- The Stern Review, Cambridge University Press.

Tang, K., Robinson, D. A., \& Harvey, M. Sustainability Managers or Rogue Mid-Mangers: A Typology of

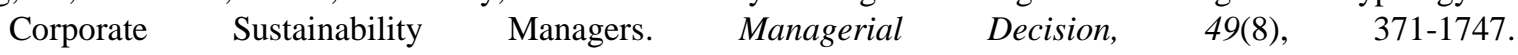
http://dx.doi.org/101108/0025174111163719

Unilever. CSR Unilever's Sustainable Living www.tutor2u.net/blog/index.php/business-studies/comments/csr-unilevers-sust...

Visser, W., Matten, D., Pohl, M., \& Tolhurst, N. (2010). Revised Ed, "The A-Z of Corporate Social Responsibility, Chichester, Wiley \& Sons Ltd.

Von Bertalanffy, L. (1951). General Systems Theory: A New Approach to Unity to Unity of Science. Human Biology, 23(4), 303-361.

(cc) BY

This work is licensed under a Creative Commons Attribution 3.0 License. 